УДК УДК 504.54(477.53)

Писаренко П. В., доктор сільськогосподарських наук, Самойлік М. С., доктор економічних наук,

Диченко О. Ю., кандидат сільськогосподарських наук

Полтавська державна аграрна академія

\title{
ЛАНДШАФТНО-ЕКОЛОГІЧНЕ РІЗНОМАНІТТЯ ТЕРИТОРІЇ ПОЛТАВСЬКОЇ ОБЛАСТІ
}

\section{Рецензент - доктор сільськогосподарських наук В. М. Писаренко}

Мета статmі- дослідження і визначення типів землекористування та показників ландмафтноекологічного різноманіття території Полтавської області за даними дистанційного зондування Землі (Global Land Cover 2000 Project).

Методика дослідження. Для визначення типів використання земель у межах досліджуваної території був використаний метод аналізу даних дистанційного зондування Землі (GLC 2000).

Результати дослідження. У статті наведені дані щодо ландшафтно-екологічного різноманіття типів покриву Полтавської області за даними дистаниійного зондування Землі. В результаті проведених досліджень та відповідних розрахунків було встановлено, що найбільше ландмафтноекологічне різноманіття характерне для східних і иентральних районів Полтавської області. Найбільше воно є характерним для Решетилівського та Великобагачанського районів, які знаходяться 6 иентрі досліджуваної області, а найменші показники ландмафтного різноманіття були характерні для Чорнухінського, Семенівського, Глобинського та Кобелящького районів. Рівень ландшафтного різноманіття в умовах Полтавської області передусім визначається співвідноменням агроекосистем до ландшафтних комплексів інших типів.

Елементи наукової новизни. Здійснено оцінку ландшафтно-екологічного різноманіття Полтавської області та досліджено його динаміку на основі даних дистаниійного зондування поверхні Землі MODIS.

Практична значущість. Аналіз типів покриву земної поверхні у межах Полтавської області показав значну розораність території та ї̈ зайнятість агроекосистемами. Ландмафтне різноманіття формувалося за рахунок ріллі, територій з мозаїкою ріллі й трав'янистого покриву та територій з розрідженим рослинним покривом.

Компоненти природних екосистем були зосереджені у заплавах річок регіону та представлені заплавними лісами, лугами та болотами.

Ключові слова: ландшафтний покрив, ландшафтне різноманіття, Полтавська область, райони, агроекосистеми, індекс Шеннона.

Писаренко Павло Вікторович - доктор сільськогосподарських наук, професор, академік інженерної Академії України, перший проректор, Полтавська державна аграрна академія, вул. Сковороди, 1/3, м. Полтава, 36003, Україна, e-mail: pavlo.pysarenko@pdaa.edu.ua, ORCID ID: 0000-0002-4915$265 \mathrm{X}$.

Самойлік Марина Сергіївна - доктор економічних наук, професор, завідувач кафедри екології, збалансованого природокористування та захисту довкілля, Полтавська державна аграрна академія, вул. Сковороди, 1/3, м. Полтава, 36003, Україна, e-mail: kaf.ekol.pdaa@ukr.net, ORCID ID: 0000-00032410-865X.

Диченко Оксана Юріївна - кандидат сільськогосподарських наук, доцент кафедри екології, збалансованого природокористування та захисту довкілля, Полтавська державна аграрна академія, вул. Сковороди, 1/3, м. Полтава, 36003, Україна, e-mail: ksenijadichenko84@ukr.net, ORCID ID: 00000003-0113-9998.

Постановка проблеми. Сучасні технології дистанційного зондування поверхні Землі з космосу та обробки просторово-координованих даних дозволяють провести глобальну типізацію ландшафтноекологічного покриву.

Головною метою Європейської комісії «Глобальний покрив Землі 2000» було створити у 2000 році глобальну гармонізовану базу даних покриву для всієї планети. Результати GLC 2000 класифікації типів поверхні Землі мають просторову точність 


\section{СІЛЬСЬКЕ ГОСПОДАРСТВО. ЕКОЛОГІЯ}

1 км. Пізніше були створені продукти, які надають можливість щорічно одержувати інформацію про структуру типів покриву Землі. Наприклад, продукт MODIS (MCD12Q1) містить щорічну інформацію про структуру покриву Землі та має роздільну здатність 500 м. Первинна схема класифікації земної поверхні, яка міститься у продукті MCD12Q1, - це IGBP (International Geosphere Biosphere Programme Міжнародна геосферно-біосферна програма) [6]. Також цей продукт містить схему класифікації Мерилендського університету [9], Біомну класифікацію (Running et al., 1994), LAI/fPAR біомну класифікацію [10] та схему функціональних типів рослинності PFT (Plant functional type) [7].

Аналіз останніх досліджень і публікацій, у яких започатковано розв'язання цісї проблеми. Ядром сучасного ландшафтознавства як природничої науки про землю є дослідження правил міжкомпонентних відносин у просторі-часі. Концепція про елементарні грунтові процеси, що у своїй основі сформульована І. П. Герасимовим та М. А. Глазовською [1] і найбільш широко розвинена Ф. І. Козловським [3] у вигляді уявлення про ландшафтні або геосистемні елементарні процеси. Цю концепцію можна розглядати як природний для натураліста підхід редукції системи до ії незалежних основ або частин [4].

Як зазначають Д. Н. Козлов і співавтори [2], можливості дослідження істотно розширюються при сполученні наземних польових вимірювань і дистанційної інформації. Остання розглядається не як засіб для дешифрування апріорі існуючих образів стану земної поверхні, а як система вимірювання іiі фізичних властивостей через величини відбитої сонячної радіації в різних спектральних зонах [5]. Поряд 3 дистанційною інформацією природно розглядати цифрові моделі рельєфу, що потенційно відбивають просторовий перерозподіл тепла, твердого й рідкого стоку $[2,5]$.

Перетворення сонячної енергії, представленої за допомогою спектрозональних дистанційних вимірювань, можна трактувати як інтегральний ландшафтний процес. Завдання дослідження в розчленуванні його на елементарні ландшафтні процеси в розумінні їх Ф. І. Козловським [3]. Елементарний процес - це методологічний прийом подання динаміки складної реальної системи, даної спостерігачеві в сукупності спостережуваних або вимірюваних змінних, а функціональний простір є моделлю явища у просторі фізично осмислених матеріальних тіл або сил. При цьому ми розраховуємо, що перше є в остаточному підсумку відображення другого [4].

Метою даної роботи є встановити показники ландшафтно-екологічного різноманіття території
Полтавської області за даними дистанційного зондування Землі.

Основним завданням було визначити рівень ландшафтно-екологічного різноманіття в Центральному Лісостепі України на прикладі Полтавської області.

Матеріали і методи досліджень. Для оцінки типів використання земель були застосовані результати програми глобального моніторингу покриву Землі - Global Land Cover 2000 Project (GLC 2000) [8]. Класифікація типів покриву Землі проведена шляхом обробки знімків, які робилися щодня протягом 14 місяців із супутника SPOT 4. Проект GLC 2000 використовує класифікаційну систему типів покриву Землі ФАО (FAO Land Cover Classification System - LCCS). Це ієрархічна класифікація, що дозволяє описати типи рослинності для кожного регіону з подальшою деталізацією, найбільшою мірою придатною для експертизи ландшафтного різноманіття регіону, відповідно до стандартизованого підходу для класифікації. Система LCCS дає можливість регіональні легенди карт транслювати у більш загальні класи типів покриву Землі для такого глобального продукту, яким є GLC 2000.

Результати досліджень. Одержані результати аналізу типів покриву земної поверхні у межах Полтавської області на основі GLC 2000підходу свідчать про те, що значна територія досліджуваної області є розораною та зайнята агроекосистемами. У межах земель сільськогосподарського призначення ландшафтне різноманіття формується за рахунок ріллі, територій $з$ мозаїкою ріллі й трав'янистого покриву та територій 3 розрідженим рослинним покривом.

Очевидно, що ці назви одиниць типів земного покриву, які застосовуються для глобальної класифікації у рамках GLC 2000-підходу, у реаліях Полтавської області відповідають різним фазам агротехнологічного циклу. Компоненти природних екосистем зосереджені у заплавах річок регіону та представлені заплавними лісами, лугами та болотами. Заплави річок можна розрізняти як такі, що представлені переважно лісовими або луговими та болотними екосистемами.

Картографічне відображення структури ландшафтного покриву земної поверхні надає можливість обрахувати зональні статистики й таким чином визначити співвідношення головних типів покриву в межах адміністративних районів Полтавської області (див. табл.). 


\begin{tabular}{|c|c|c|c|c|c|c|c|c|c|c|c|c|c|c|c|c|c|c|c|c|c|c|c|c|c|c|}
\hline 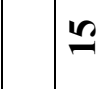 & 1 & స̂. & $\int_{0}^{\infty}$ & 1 & 1 & 1 & & & 1 & 1 & 1 & fr. & $\stackrel{R}{=}$ & 1 & 1 & 1 & 1 & I & 1 & $\left|\begin{array}{l}t \\
0 \\
f\end{array}\right|$ & 1 & 1 & 1 & 1 & 1 & . \\
\hline$\Xi$ & 1 & $\begin{array}{l} \\
0 \\
0\end{array}$ & 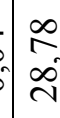 & 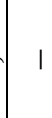 & 1 & 1 & & 7 & $\underline{\underline{6}}$ & 1 & 1 & $\begin{array}{l} \pm \\
\infty \\
\Omega\end{array}$ & 1 & 1 & 1 & 1 & 1 & 1 & 1 & 이 & 1 & $\left|\begin{array}{l}n \\
0\end{array}\right|$ & 1 & 1 & 1 & 1 \\
\hline$\stackrel{m}{=}$ & 1 & 1 & $\begin{array}{l}0 \\
0 \\
0\end{array}$ & I & 1 & 1 & & 8 & $\begin{array}{l}0 \\
0 \\
0\end{array}$ & 1 & 1 & \begin{tabular}{l}
\multirow{2}{*}{} \\
0
\end{tabular} & 1 & 1 & 1 & 1 & 1 & I & 1 & I & 1 & 1 & 1 & 1 & 1 & 1 \\
\hline $\mathcal{Z}$ & $\begin{array}{l}\mathbb{t} \\
\dot{J}\end{array}$ & $\frac{ \pm}{n}$ & $=\frac{9}{0}$ & $\frac{1}{\infty}$ & $\stackrel{\infty}{\stackrel{\infty}{2}}$ & $\hat{h}$ & $\begin{array}{lll}0 & 5 \\
0 & = & 5\end{array}$ & 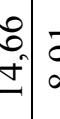 & $\bar{\alpha}$ & $\begin{array}{l}\stackrel{\nabla}{t} \\
\dot{ \pm}\end{array}$ & $\begin{array}{l}\tilde{y} \\
\hat{\imath}\end{array}$ & $\begin{array}{l}\bar{a} \\
\hat{n}\end{array}$ & \begin{tabular}{c}
0 \\
\hdashline \\
-2
\end{tabular} & $\begin{array}{l}\tilde{N} \\
\end{array}$ & $\begin{array}{l}8 \\
\mathfrak{1}\end{array}$ & $\hat{b}$ & $\begin{array}{l}0 \\
0 \\
0\end{array}$ & $\begin{array}{l}F \\
\pm\end{array}$ & $\mid \begin{array}{l}\infty \\
\tilde{n} \\
n \\
n\end{array}$ & $\begin{array}{l}\mathcal{6} \\
\sigma\end{array}$ & $\begin{array}{l}\bar{n} \\
0 \\
0\end{array}$ & $\mid \begin{array}{l}+ \\
\infty \\
0 \\
-0\end{array}$ & 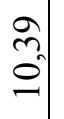 & 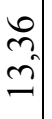 & $\begin{array}{l}\infty \\
\\
\stackrel{2}{2}\end{array}$ & 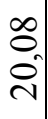 \\
\hline$=$ & $=\frac{0}{n}$ & 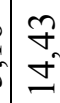 & m & 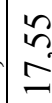 & $\frac{ \pm}{2}$ & 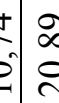 & 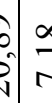 & $\begin{array}{c}\infty \\
-\end{array}$ & $\frac{n}{6}$ & $\frac{\Xi}{n}$ & $\begin{array}{l}\overrightarrow{\gamma^{\prime}} \\
\stackrel{0}{0}\end{array}$ & $\begin{array}{l}8 \\
8 \\
n\end{array}$ & 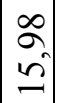 & $\begin{array}{l}\hat{b} \\
\dot{ \pm}\end{array}$ & $\begin{array}{l}\vec{\infty} \\
\forall\end{array}$ & $\begin{array}{l}n \\
n \\
n\end{array}$ & $\begin{array}{l}\infty \\
0 \\
a\end{array}$ & $\begin{array}{l}\infty \\
n \\
\infty\end{array}$ & $\begin{array}{c}\sigma \\
0 \\
n\end{array}$ & $\begin{array}{l}0 \\
\infty \\
0 \\
0\end{array} \mid$ & $\begin{array}{l}n \\
n \\
\nabla\end{array}$ & $\begin{array}{l}2 \\
\alpha \\
\infty\end{array} \mid$ & $\begin{array}{l}n \\
= \\
=\end{array}$ & $\begin{array}{l}\infty \\
\infty \\
\infty\end{array}$ & 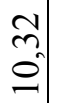 & $\begin{array}{c}m \\
0 \\
m\end{array}$ \\
\hline \begin{tabular}{c|c}
$*$ & 0 \\
$0^{\circ}$ & $=$
\end{tabular} & 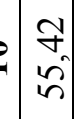 & $\frac{5}{6}$ & $\begin{array}{l}0 \\
b \\
b\end{array}$ & $\begin{array}{l}n \\
n \\
8 \\
0\end{array}$ & $\begin{array}{l}5 \\
0 \\
\sigma\end{array}$ & $\begin{array}{l}7 \\
\vdots \\
6 \\
0\end{array}$ & $\begin{array}{ll}7 \\
2 \\
2\end{array}$ & 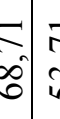 & 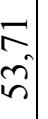 & $\begin{array}{l}\frac{9}{8} \\
8 \\
0\end{array}$ & $\begin{array}{l}0 \\
+ \\
\infty \\
n \\
n\end{array}$ & $\begin{array}{l}8 \\
0 \\
5\end{array}$ & $\begin{array}{l}\hat{n} \\
\hat{n}\end{array}$ & $\begin{array}{l}n \\
n \\
n \\
n\end{array}$ & $\begin{array}{c}\mathcal{1} \\
0 \\
0 \\
0\end{array}$ & ป & $\begin{array}{l}9 \\
\dot{\theta} \\
\delta\end{array}$ & $\mid \begin{array}{l}\infty \\
+ \\
i n \\
i n\end{array}$ & $\begin{array}{l}\tilde{z} \\
\tilde{H} \\
n\end{array}$ & $\begin{array}{l}n \\
n \\
n \\
n\end{array}$ & $\frac{n}{2}$ & $\mid \begin{array}{c}\hat{\jmath} \\
\hat{\sigma} \\
\hat{6}\end{array}$ & $\begin{array}{c}\vec{n} \\
?\end{array}$ & $\begin{array}{l}\infty \\
\infty \\
\infty \\
i\end{array}$ & तิ & $\begin{array}{l}\text { के } \\
\hat{\sigma}\end{array}$ \\
\hline 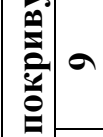 & $\begin{array}{l}0 \\
0 \\
0 \\
0\end{array}$ & $\frac{n}{0}$ & ?े? & $\overline{0}$ & I & 1 & & । & $\begin{array}{l}\text { f. } \\
0\end{array}$ & 1 & I & $\vec{c}$ & $\begin{array}{l}f_{+} \\
0\end{array}$ & $\vec{m}$ & $\hat{0}$ & 公 & $\frac{ \pm}{0}$ & $\left\{\begin{array}{l}\infty \\
n \\
0\end{array}\right.$ & 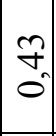 & $\begin{array}{l}n \\
f \\
0 \\
0\end{array}$ & 1 & $\left|\begin{array}{l}0 \\
0 \\
0 \\
0\end{array}\right|$ & $\begin{array}{l}0 \\
0 \\
0\end{array}$ & & 1 & $\begin{array}{l}\infty \\
0 \\
0\end{array}$ \\
\hline 是 & $\left|\begin{array}{c}\hat{\sigma} \\
n\end{array}\right|$ & $\stackrel{8}{-}$ & $\begin{array}{l}8 \\
\text { m }\end{array}$ & $\frac{n}{0}$ & $\stackrel{\text { ㄱ}}{-}$ & 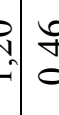 & $\begin{array}{l}f \\
f\end{array}$ & $\begin{array}{c}n \\
\vdots \\
0 \\
0\end{array}$ & $\begin{array}{l}\hat{\sigma} \\
\hat{i}\end{array}$ & $\frac{\infty}{\infty}$ & $\begin{array}{l}0 \\
n \\
0\end{array}$ & $\stackrel{8}{\stackrel{8}{n}}$ & $\begin{array}{l}2 \\
0 \\
0 \\
0\end{array}$ & $\hat{\sigma}$ & $\begin{array}{l}\infty \\
1 \\
0 \\
0\end{array}$ & $\tilde{n}$ & $\begin{array}{l}\infty \\
n \\
0 \\
0\end{array}$ & $\stackrel{8}{-}$ & $\left|\begin{array}{l}0 \\
\infty \\
0 \\
0\end{array}\right|$ & 음 & $\hat{\kappa}$ & $\begin{array}{l}m \\
\tilde{m} \\
m\end{array} \mid$ & $\begin{array}{l}\tilde{0} \\
\hat{\mathrm{N}}\end{array}$ & \begin{tabular}{l}
0 \\
\multirow{2}{*}{} \\
0
\end{tabular} & 1 & $\begin{array}{l}\text { ते } \\
\text { in }\end{array}$ \\
\hline$r$ & $\begin{array}{l}1 \\
0 \\
6 \\
0\end{array}$ & $\begin{array}{l}\text { in } \\
\text { n }\end{array}$ & $\begin{array}{l}0 \\
n \\
n\end{array}$ & $\hat{\sigma}$ & $\stackrel{f}{f}$ & $\begin{array}{lll}f & n \\
f & n\end{array}$ & $\hat{\imath} 20$ & 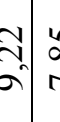 & $\begin{array}{l}n \\
\infty \\
- \\
\sim\end{array}$ & $\begin{array}{l}\overline{6} \\
n\end{array}$ & $\begin{array}{l}0 \\
n \\
n \\
n\end{array}$ & $\begin{array}{l}\text { in } \\
\text { in }\end{array}$ & $\frac{n}{m}$ & $\begin{array}{l}\hat{n} \\
\hat{\jmath}\end{array}$ & $\stackrel{m}{\simeq}$ & సู & r & $\stackrel{\substack{\gamma \\
\pm}}{ }$ & $\begin{array}{l}\dot{\sigma} \\
\sigma \\
0\end{array}$ & $\begin{array}{l}- \\
\infty \\
-\end{array}$ & $\underset{\mho}{テ}$ & 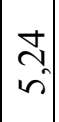 & 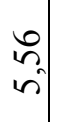 & బิ & $\begin{array}{l}0 \\
\vdots \\
0 \\
0\end{array}$ & $\begin{array}{c}\infty \\
\text { ஸे } \\
\text { m. }\end{array}$ \\
\hline 恶 & 1 & I & 1 & $\stackrel{?}{\tilde{\sigma}}$ & I & I & & 1 & 1 & 1 & 1 & 1 & సે. & $\frac{\infty}{0}$ & $\hat{0}$ & 1 & 1 & \&. & ปे & 1 & 1 & $\left|\begin{array}{l}n \\
0 \\
0\end{array}\right|$ & $\begin{array}{c}1 \\
0\end{array}$ & 1 & I & 1 \\
\hline in & 1 & I & 1 & 1 & 1 & I & & 1 & 1 & 1 & 1 & $\stackrel{0}{\circ}$ & I & 1 & 1 & 1 & 1 & 1 & 1 & I & 1 & I & I & 1 & 1 & 1 \\
\hline$\nabla$ & $\stackrel{\infty}{\stackrel{\infty}{=}}$ & సิ & $\begin{array}{l}\approx \\
0 \\
0\end{array}$ & $\tilde{3}$ & I & I & & 1 & $\begin{array}{l}n \\
n \\
o\end{array}$ & 1 & $\begin{array}{l}\infty \\
0 \\
0 \\
0\end{array}$ & $\stackrel{m}{=}$ & 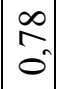 & స̃ & $\stackrel{\sim}{\underset{t}{0}}$ & $\begin{array}{l}m \\
0 \\
0\end{array}$ & $\stackrel{ \pm}{\sim}$ & 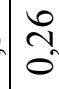 & ปู & $\begin{array}{l}2 \\
6 \\
0 \\
0\end{array}$ & 1 & $\left|\begin{array}{c}0 \\
2 \\
0\end{array}\right|$ & ণै. & $\begin{array}{c}\infty \\
\infty \\
0 \\
0\end{array}$ & 1 & $\frac{1}{0}$ \\
\hline$m$ & $=\begin{array}{l}\hat{\gamma} \\
0\end{array}$ & $\stackrel{\infty}{m}$ & $\frac{0}{0}$ & ป̂ & $\begin{array}{l}0 \\
+ \\
0\end{array}$ & $\begin{array}{l}\dot{0} \\
\dot{f} \\
b\end{array}$ & & I & $\frac{m}{0}$ & I & 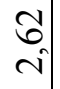 & : & $\frac{n}{0}$ & $\begin{array}{l}\Delta \\
0 \\
0\end{array}$ & $\begin{array}{l}\hat{0} \\
0 \\
0\end{array}$ & ปે & $\stackrel{\Xi}{\Delta}$ & co & $\frac{a}{0}$ & $\frac{n}{r}$ & 1 & $\left|\begin{array}{l}n \\
0 \\
0\end{array}\right|$ & I & $\stackrel{\sim}{\approx}$ & $\begin{array}{l}\hat{0} \\
0 \\
0\end{array}$ & 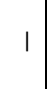 \\
\hline$N$ & $\left|\begin{array}{c}8 \\
0 \\
\infty\end{array}\right|$ & F & $=\left[\begin{array}{l}2 \\
\tilde{\sigma}\end{array}\right.$ & స̃ & 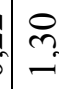 & $=$ & & & $\begin{array}{l}+ \\
\infty \\
0\end{array} \mid$ & กิ & $\begin{array}{l}\hat{\sigma} \\
\hat{\sigma}\end{array} \mid$ & $\begin{array}{c}\sigma \\
0 \\
0\end{array}$ & $\begin{array}{l}n \\
0 \\
0\end{array} \mid$ & $\begin{array}{l}1 \\
0 \\
0\end{array}$ & $\bar{\sigma}$ & \begin{tabular}{l}
$n$ \\
\multirow{1}{*}{} \\
$c$
\end{tabular} & $\begin{array}{l}n \\
\tilde{n} \\
i\end{array}$ & $\begin{array}{l}8 \\
0 \\
0\end{array}$ & $\frac{7}{0}$ & $\left|\begin{array}{l}\infty \\
\hat{\sigma} \\
n\end{array}\right|$ & 1 & {$\left[\begin{array}{l}n \\
n \\
0\end{array}\right]$} & 1 & $\begin{array}{l}2 \\
0 \\
0\end{array}$ & 1 & है. \\
\hline- & $\begin{array}{c}0 \\
n \\
0\end{array}$ & $\frac{\hat{2}}{0}$ & $\begin{array}{l}2 \\
0 \\
0\end{array}$ & స̃ & $\infty$ & $\hat{\theta}$ & $\begin{array}{l}0 \\
= \\
=\end{array}$ & $\begin{array}{l}\infty \\
0 \\
0 \\
0 \\
0\end{array}$ & $\begin{array}{l}\stackrel{0}{+} \\
0 \\
0\end{array}$ & I & $\begin{array}{l}0 \\
+ \\
0\end{array}$ & $\approx$ & $\mid$ & $\vec{a}$ & $\begin{array}{l}\infty \\
\\
0\end{array}$ & $\frac{0}{2}$ & $\begin{array}{l}\stackrel{ \pm}{J} \\
0\end{array}$ & 市 & $\begin{array}{l}\infty \\
0 \\
0\end{array}$ & $\mid \begin{array}{l}n \\
n \\
0\end{array}$ & 1 & 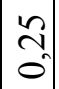 & ○. & बू. & $\mid$ & I \\
\hline E & 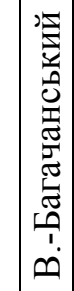 & 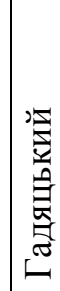 & 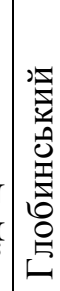 & 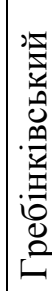 & | & 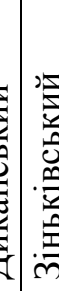 & 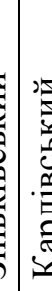 & 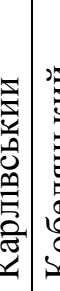 & 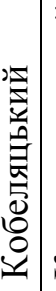 & 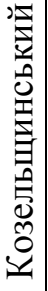 & $\begin{array}{c}2 \\
5 \\
5 \\
0 \\
0 \\
0 \\
0 \\
0 \\
0 \\
0 \\
0 \\
0\end{array}$ & 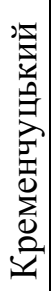 & 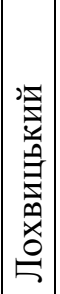 & 步 & 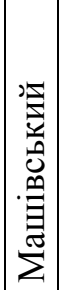 & 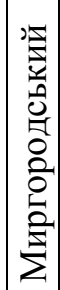 & 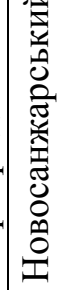 & 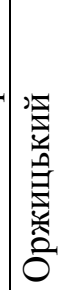 & 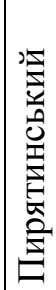 & 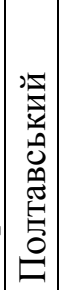 & 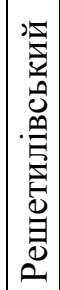 & 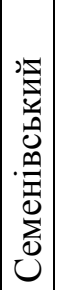 & 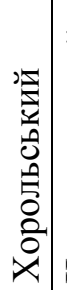 & 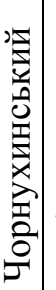 & 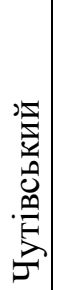 & 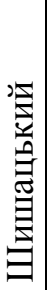 \\
\hline 竞 & - & $N$ & $m$ & $\nabla$ & $n$ & 0 & r & $\infty$ & $\infty$ & $a$ & $\stackrel{0}{ }$ & $=$ & $\beth$ & $\cong$ & $\Xi$ & 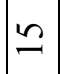 & 0 & 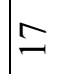 & $\infty$ & 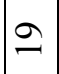 & 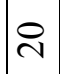 & $\vec{\sim}$ & $\approx$ & $\hat{\imath}$ & 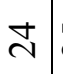 & $\approx$ \\
\hline
\end{tabular}




\section{СІЛЬСЬКЕ ГОСПОДАРСТВО. ЕКОЛОГІЯ}

Примітка *: 1) широколистяні ліси; 2) змішані ліси; 3) гумідний грасленд; 4) прибережна лісово-лугова рослинність; 5) пал; 6) чагарник; 7) трав'янистий покрив; 8) розріджений рослинний покрив; 9) заплави; 10) агроекосистеми; 11) мозаїка ріллі та лісу; 12) мозаїка ріллі та трав'янисто-го покриву; 13) відкрита поверхня; 14) водна поверхня; 15) штучні поверхні.

Джерело: авторські дослідження.

У результаті проведених досліджень встановлено, що агроекосистеми (разом із мозаїкою та природною рослинністю) є найбільшим за площею типом покриву та займають від 56,6 \% (Кременчуцький район) до 92,94 \% (Шишацький район) території адміністративних районів. Частка складних мозаїчних агроекосистем (мозаїки 3 лісовою або луговою рослинністю) від площі суцільних агроекосистем становить від 24,12\% (Кременчуцький район) до 63,38 \% (Чорнухинський район). Складний характер мозаїк дозволяє припустити більш високий рівень біологічного різноманіття цих типів земної поверхні. У межах мозаїчних ландшафтних комплексів вірогідне існування рефугіумів хижих членистоногих, які здатні виконувати регулюючі функції в агроекосистемах. Площа трав'янистого покриву (луги, вологі луги, або грассленд, заплавні болота) займають друге місце у структурі ландшафтного покриву регіону. Ця група типів складає від 3,36 \% (Шишацький район) до 15,37 \% (Оржицький район) площі адміністративних районів. На відміну від агроекосистем, природні трав'янисті комплекси розташовані дифузно, оскільки пов'язані із заплавами річок або іншими депресіями рельєфу (балки, байраки).

Наслідком дифузного характеру просторового розподілу є значна відносна довжина границі 3 навколишніми типами покриву, якими $\epsilon$ пере- важно агроекосистеми. У зв'язку 3 цим трав'янисті екосистеми потрібно розглядати як важливе джерело інвазії в агроекосистеми тварин-хижаків.

Полтавська область знаходиться в межах лісостепової зони, але лісовий покрив представлений на дуже обмеженій території. Так, лісові масиви, які можна ідентифікувати за даними дистанційного зондування поверхні Землі засобами супутника MODIS, майже відсутні у Решетилівському, Хорольському, Карлівському, Козельщинському районах. Лісові масиви в межах цих адміністративних одиниць представлені фрагментами у рамках більш складних мозаїчних комплексів. Значну площу лісові масиви займають у Кременчуцькому $(8,07$ \%), Гадяцькому $(8,18$ \%), Великобагачанському $(8,90 \%)$ та Котелевському $(10,09 \%)$ районах.

Штучні поверхні представлені урбанізованими територіями та пов'язані з розташуванням у межах області міських населених пунктів. Інші типи земної поверхні складають незначні за площею ділянки та не формують регулярних або закономірних патернів.

Сукупність типів земної поверхні може бути відображенням ландшафтно-екологічного різноманіття. Цей показник кількісно був визначений за допомогою індексу Шеннона (біт/піксель) (див. рис.).

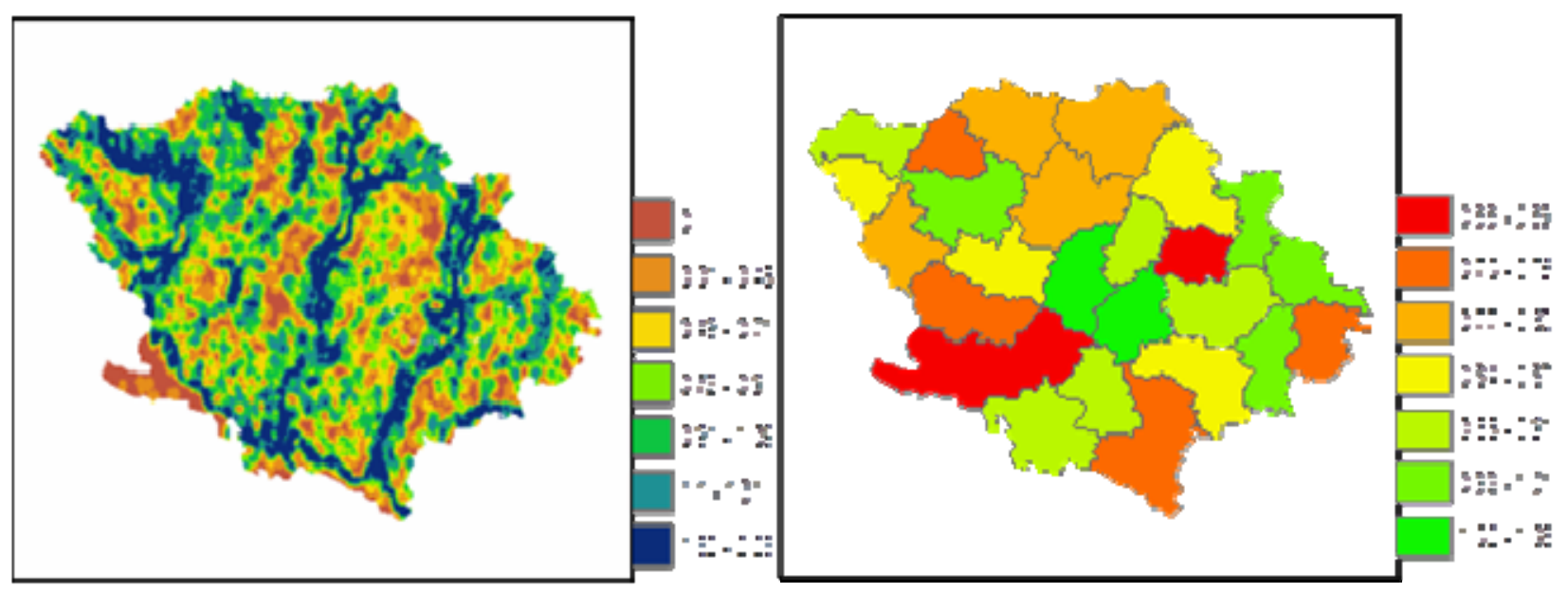

Рис. Ландиафтно-екологічне різноманіття Полтавськой області

Примітка: зліва - просторове варіювання індексу;

справа - зональна статистика за адміністративними районами області.

Джерело: авторські дослідження. 


\section{СІЛЬСЬКЕ ГОСПОДАРСТВО. ЕКОЛОГІЯ}

\section{Висновки:}

1. У результаті проведених досліджень авторами було виявлено, що найбільше ландшафтноекологічне різноманіття характерне для східних і центральних районів Полтавської області.

2. Найбільше ландшафтне різноманіття досліджуваної області встановлене для Решетилівського (у середньому індекс Шеннона становить 1,07 біт/піксель) та Великобагачанського (1,06 біт/піксель) районів, розташованих у центрі Полтавської області.

\section{БІБЛІОГРАФІЯ}

1. Герасимов И. П., Глазовская М. А. Основы почвоведения и географии почв. Москва : Высшая школа, 1960. 236 с.

2. Козлов Д. Н., Пузаченко М. Ю., Федяева $M . B$. Отображение пространственного варьирования свойств ландшафтного покрова на основе дистанционной информации и цифровой модели рельефа : Изд. РАН. Сер. Географ. № 4. 2008. C. 112-124.

3. Козловский Ф. И. Теория и методы изучения почвенного покрова. Москва : ГЕОС, 2003. $536 \mathrm{c}$.

4. Пузаченко Ю. Г. Методологические основания отображения элементарных геосистемных процессов. Современные естественные и антропогенные процессы в почвах геосистем. [М. В. Федяева, Д. Н Козлов и др.], Москва : Почв. ин-т им. В. В. Докучаева, 2006. С. 13-52.

5. Пространственная агроэкология и рекультивация земель : монография / Демидов А. А., Кобец А. С., Грицан Ю. И., Жуков А. В. Днепропетровск : Изд-во «Свидлер А. Л.», 2013. $560 \mathrm{c}$.

6. Belward A. S., Estes A. S., Kline K. D. The IGBP-DIS Global 1-km Land-Cover Data Set

\section{REFERENCE}

1. Herasymov, Y.P., Hlazovskaia, M.A. (1960). Osnovy pochvovedenyia y heohrafyy pochv [Fundamentals of soil science and soil geography]. Moskva: Vysshaia shkola [In Russian].

2. Kozlov, D.N., Puzachenko, M.Yu., Fediaeva, M.B. (2008). Otobrazhenye prostranstvennoho varyrovanyia svoistv landshaftnoho pokrova na osnove dystantsyonnoi ynformatsyy y tsyfrovoi modely relefa [Display of spatial variation of landscape cover properties based on distance information and digital elevation model]. Yzd. RAN. Ser. Heohraf, 4, pp. 112-124 [In Russian].

3. Kozlovskyi, F.Y. (2003). Teoryia y metody yzuchenyia pochvennoho pokrova [Theory and
3. Найменше ландшафтне різноманіття в області властиве для Чорнухінського, Семенівського, Глобинського та Кобеляцького районів.

Перспективи подальшої роботи в цьому напрямі. Перспективами подальших досліджень є встановлення залежності рівня варіювання шкідливих комах від ландшафтно-екологічного різноманіття та визначення характеру впливу динаміки ландшафтно-екологічного покриву на динаміку популяцій шкідливих комах.

DISCover: A Project Overview. Photogrammetric, Engineering and Remote Sensing. 1999. Vol. 65. P. 1013-1020.

7. Bonan G. B., Oleson K. W., Vertenstein M., Levis S., Zeng X. B., Dai $Y$. The land surface climatology of the community land model coupled to the NCAR community land model. Journal of Climate. 2002. Vol. 15. P. 3123-3149.

8. Global Land Cover 2000 database. European Commission, Joint Research Centre. 2003. URL: http://bioval.jrc.ec.europa.eu/products/glc2000/ glc2000.php.

9. Hansen M. C., DeFries R. S., Townshend J. R. G. Global land cover classification at the $1 \mathrm{~km}$ spatial resolution using a classification tree approach. International Journal of Remote Sensing. 2000. Vol. 21. P. 1331-364.

10. Myneni R. B., Nemani R. R., Running S. W. Estimation of global leaf area index and absorbed PAR using radiative transfer model. IEEE Transactions on Geoscience and Remote Sensing. 1997. Vol. 35. P. 1380-1393.

methods of studying the soil cover]. Moskva: HEOS [In Russian].

4. Puzachenko, Yu.H. (2006). Metodolohycheskye osnovanyia otobrazhenyia elementarnykh heosystemnykh protsessov [Methodological bases of mapping elementary geosystem processes]. Sovremennye estestvennye y antropohennye protsessy $\mathrm{v}$ pochvakh heosystem. Moskva: Pochv. yn-t ym. V.V. Dokuchaeva [In Russian].

5. Demydov, A.A., Kobets, A.S., Hrytsan, Yu.Y., Zhukov, A.V. (2013). Prostranstvennaia ahroekolohyia y rekultyvatsyia zemel: monohrafyia [Spatial agroecology and land recla- 


\section{СІЛЬСЬКЕ ГОСПОДАРСТВО. ЕКОЛОГІЯ}

mation: monograph]. Dnepropetrovsk: Yzd-vo «Svydler A.L.» [In Ukrainian].

6. Belward, A.S., Estes, A.S., Kline, K.D. (1999). The IGBP-DIS Global 1-km Land-Cover Data Set DISCover: A Project Overview. Photogrammetric, Engineering and Remote Sensing, 65. pp. 1013-1020 [In English].

7. Bonan, G.B., Oleson, K.W., Vertenstein, M., Levis, S., Zeng, X.B., Dai, Y. (2002). The land surface climatology of the community land model coupled to the NCAR community land model. Journal of Climate, 15. pp. 3123-3149 [In English].

8. Global Land Cover 2000 database. European Commission, Joint Research Centre. 2003. URL: http://bioval.jrc.ec.europa.eu/products/glc2000/ glc2000.php [In English].

9. Hansen, M.C., DeFries, R.S., Townshend, J.R.G. (2000). Global land cover classification at the $1 \mathrm{~km}$ spatial resolution using a classification tree approach. International Journal of Remote Sensing, 21, pp. 1331-1364 [In English].

10. Myneni, R.B., Nemani, R.R., Running, S.W. (1997). Estimation of global leaf area index and absorbed PAR using radiative transfer model. IEEE Transactions on Geoscience and Remote Sensing, 35, pp. 1380-1393 [In English].

\section{Писаренко П. В., Самойлик М. С., Дыченко О. Ю. Ландиафтно-экологическое разнообразие территории Полтавской области}

Цель статьи - исследование и определение типов землепользования и показателей ландмафтноэкологического разнообразия территории Полтавской области по данным дистаниионного зондирования Земли (Global Land Cover 2000 Project).

Методика исследования. Основой исследований оценки типов использования земель в пределах исследуемой территории служили результаты программы глобального мониторинга покрова Земли (GLC 2000).

Результаты исследования. В статье приведены данные ландиафтно-экологического разнообразия типов покрова Полтавской области по данным дистанционного зондирования Земли. В результате проведенных исследований и соответствующих расчетов было установлено, что наиболее ландшафтно-экологическое разнообразие характерно для восточных и центральных районов Полтавской области. Больше всего оно характерно для Решетиловского и Великобагачанского районов, которые находятся в иеетте исследуемой области, а наименьшие показатели ландшафтного разнообразия наблюдались в Чернухинском, Семеновском, Глобинском и Кобелячкком районах. Уровень ландшафтного разнообразия в условиях Полтавской области прежде всего определялся соотношением агроэкосистем кландшафтным комплексам других типов.

Элементы научной новизны. Осуществлена оченка ландшафтно-экологического разнообразия Полтавской области и исследована его динамика на основе данных дистанционного зондирования поверхности Земли MODIS.

Практическая значимость. Анализ типов покрова земной поверхности в пределах Полтавской области показал значительную распашку территория и ее занятость агроэкосистемами. Ландшафтное разнообразие формировалось за счет пашни, территорий с мозаикой пашни и травянистого покрова, и территорий с разреженным растительным покровом.

Компоненты природных экосистем были сосредоточень в поймах рек региона и представлень пойменными лесами, лугами и болотами.

Ключевые слова: ландшафтный покров, ландшафтное разнообразие, Полтавская область, районы, агроэкосистемы, индекс Шеннона.

Писаренко Павел Викторович - доктор сельскохозяйственных наук, профессор, академик инженерной Академии Украины, первый проректор, Полтавская государственная аграрная академия, ул. Сковороды, 1/3, г. Полтава, 36003, Украина, e-mail: pavlo.pysarenko@pdaa.edu.ua, ORCID ID: 00000002-4915-265X.

Самойлик Марина Сергеевна - доктор экономических наук, профессор, заведующий кафедрой экологии, сбалансированного природопользования и защиты окружающей среды, Полтавская государственная аграрная академія, ул. Сковороды, 1/3, г. Полтава, 36003, Украина, е-таil: kaf.ekol.pdaa@ukr.net, ORCID ID: 0000-0003-2410-865X.

Дыченко Оксана Юрьевна - кандидат сельскохозяйственных наук, доцент кафедры экологии, сбалансированного природопользования и защиты окружающей среды, Полтавская государственная 


\section{СІЛЬСЬКЕ ГОСПОДАРСТВО. ЕКОЛОГІЯ}

аграрная академия, ул. Сковороды, 1/3, г. Полтава, 36003, Украина, e-mail: ksenijadichenko84@ukr.net, ORCID ID: 0000-0003-0113-9998.

Pysarenko P. V., Samoilik M. S., Dychenko O. Yu. Landscape-ecological diversity of the territory of Poltava region

The purpose of the article is to study and determine the types of land use and indicators of landscape and ecological diversity of the territory of Poltava region according to the data of the remote sensing of the Earth (Global Land Cover 2000 Project).

Methods of research. The method of analysis of the Earth remote sensing data (GLC 2000) was used to determine the types of land use within the studied area.

The research results. The data on the landscape-ecological diversity of the cover types in Poltava region according to the data of remote sensing of the Earth have been given in the article. As a result of the conducted research and corresponding calculations it has been established that the largest landscape and ecological diversity is characteristic for the eastern and central districts of Poltava region. It is the most characteristic of Reshetylivka and Velyka Bahachka districts located in the center of the studied area, while the lowest indicators of landscape diversity were found in Chornukhy, Semenivka, Hlobyno and Kobeliaky districts. The level of landscape diversity in Poltava region is primarily determined by the ratio of agroecosystems to landscape complexes of other types.

The elements of scientific novelty. The assessment of the landscape and ecological diversity of Poltava region has been carried out and its dynamics based on the data of MODIS remote sensing of the Earth's surface has been studied.

Practical significance. The analysis of the cover types of the Earth's surface within Poltava region has shown significant plowing of the territory and its occupation with agro-ecosystems. Landscape diversity was formed at the expense of arable land, territories with a mosaic of arable land, grassland and the areas with spaced vegetation cover.

The components of natural ecosystems were concentrated in river floodplains of the region and are represented by floodplain forests, meadows and swamps.

Key words: landscape cover, landscape diversity, Poltava region, districts, agro-ecosystems, Shannon index.

Pysarenko Pavlo Viktorovych - Doctor of Agricultural Sciences, Professor, Academician of Engineering Academy of Ukraine, First Vice-rector of Poltava State Agrarian Academy, 1/3, Skovorody st., Poltava, 36003, Ukraine, e-mail: pavlo.pysarenko@pdaa.edu.ua, ORCID ID: 0000-0002-4915-265X.

Samoilik Maryna Serhiivna - Doctor of Economics, Professor, Head of the Department of Ecology, Balanced Nature Management and Environmental Protection of Poltava State Agrarian Academy, 1/3, Skovorody st., Poltava, 36003, Ukraine, e-mail: kaf.ekol.pdaa@ukr.net, ORCID ID: 0000-0003-2410-865X.

Dychenko Oksana Yuriivna - Candidate $(\mathrm{PhD})$ of Agricultural Sciences, Associate Professor, Department of Ecology, Balanced Nature Mnagement and Environmental Protection of Poltava State Agrarian Academy, 1/3, Skovorody st., Poltava, 36003, Ukraine, e-mail: ksenijadichenko84@ukr.net, ORCID ID: 0000-0003-0113-9998.

Стаття надійшла до редакції 18.02.2019 р.

Бібліографічний опис для цитування :

Писаренко П. В., Самойлік М. С., Диченко О. Ю Ландшафтно-екологічне різноманіття території Полтавської області. Вісник ПДАА. 2019. № 1. С. 127-133.

DOI 10.31210/visnyk2019.01.14

(C) Писаренко Павло Вікторович, Самойлік Марина Сергіївна, Диченко Оксана Юріївна, 2019 